\title{
New records of lichens and allied fungi from the Leningrad Region, Russia. X
}

\author{
Dmitry E. Himelbrant ${ }^{1,2}$, Irina S. Stepanchikova ${ }^{1,2}$, Jurga Motiejūnaité丶 $\dot{e}^{3}$, Ekaterina S. \\ Kuznetsova $^{1,2}$, Gulnara Tagirdzhanova ${ }^{4}$, Ivan V. Frolov ${ }^{5}$ \\ ${ }^{1}$ Department of Botany, St. Petersburg State University, Universitetskaya emb. 7-9, 199034 St. Petersburg, Russia. \\ E-mails: d_brant@mail.ru, stepa_ir@mail.ru, igel_kuzn@mail.ru \\ ${ }^{2}$ Laboratory of Lichenology and Bryology, Komarov Botanical Institute RAS, Professor Popov St. 2, \\ 197376 St. Petersburg, Russia \\ ${ }^{3}$ Laboratory of Mycology, Institute of Botany, Nature Research Centre, Žaliųjų Ežerų 49, LT-08406 Vilnius, Lithuania. \\ E-mail: jurga.motiejunaite@gamtc.lt \\ ${ }^{4}$ Department of Biological Sciences, University of Alberta, Edmonton, Alberta T6G 2R3, Canada. \\ E-mail: gultagr@gmail.com \\ ${ }^{5}$ Institute Botanic Garden, Ural Branch of Russian Academy of Sciences, Vos'mogo Marta 202a str., \\ 620144 Yekaterinburg, Russia. E-mail: ivfrolov@gmail.com
}

\begin{abstract}
Ten lichen species and three lichenicolous fungi are reported for the first time for St. Petersburg, the whole Leningrad Region or its western part. The lichens Bacidina indigens and Lecidella asema are new for European Russia, the lichens Bryoria kuemmerleana, Caloplaca turkuensis, Scoliciosporum pruinosum, and the lichenicolous fungus Raesaenenia huuskonenii are new for North-Western European Russia.
\end{abstract}

Keywords: St. Petersburg, Bacidina indigens, Lecidella asema

\section{INTRODUCTION}

This paper continues the series of publications focused on new and noteworthy findings of lichens and allied fungi from the Leningrad Region and St. Petersburg (see, e.g., Stepanchikova et al., 2010, 2018; Kuznetsova et al., 2012; Himelbrant et al., 2016, 2017). Bacidina indigens and Lecidella asema are reported for the first time for European Russia, Bryoria kuemmerleana, Caloplaca turkuensis, Raesaenenia huuskonenii, and Scoliciosporum pruinosum are new for North-Western European Russia. Five species (Botryolepraria lesdainii, Lecidella anomaloides, Lichenopeltella peltigericola, Muellerella ventosicola, and Sclerococcum cf. attendendum) are new for the whole Leningrad Region (including St. Petersburg); two species (Bacidina neosquamulosa and Protoblastenia rupestris) are new for the western part of the Leningrad Region.

This paper contains data on the groups of species that are difficult to identify. Most of the records originate from remote places in the Leningrad Region. Our findings include some additions to recently published lichen floras of the islands of Konevets (Himelbrant et al., 2018) and Tuters (Stepanchikova et al., 2017a). The species list of Konevets includes now 438 species, and Tuters - 335 species. Ca 1130 species, including 970 lichens, 130 lichenicolous and 30 saprobic fungi, are currently recorded in the Leningrad Region and St. Petersburg.

\section{MATERIAL AND METHODS}

The paper is based mainly on specimens collected by Dmitry E. Himelbrant, Irina S. Stepanchikova, Ekaterina S. Kuznetsova, and Gulnara Tagirdzhanova in 2011-2018 in the Leningrad Region and St. Petersburg. The specimens are deposited in the lichen herbaria of St. Petersburg State University (LECB), University of Helsinki $(\mathrm{H})$, and Institute of Botany, Nature Research Centre in Vilnius (BILAS). Additionally, some older collections of lichens and lichenicolous fungi have been revised in the herbaria of Komarov Botanical Institute RAS (LE) and H. The cited specimens were mainly identified by the authors of the paper, if otherwise, the identifier's name is indicated in the annotation of the species. Chromatography was performed by 
Stepanchikova and Himelbrant according to the standard techniques of high performance thinlayer chromatography using solvent systems A and B (Orange et al., 2001). Micrographs of external characters for species were taken with Stemi-2000 CS microscope with an attached camera AxioCam MRc5.

The names of the main collectors in the species list are abbreviated as follows: DH - Dmitry E. Himelbrant, EK - Ekaterina S. Kuznetsova, GT - Gulnara Tagirdzhanova and IS - Irina S. Stepanchikova. The subdivision of the Leningrad Region (LR) was published in our previous paper (Stepanchikova et al., 2010). The following abbreviations are used here: ELR - Eastern Leningrad Region, SPb - St. Petersburg, WLR - Western Leningrad Region. The biogeographical provinces of Eastern Fennoscandia are abbreviated traditionally (Kotiranta et al., 1998): Ik - Isthmus karelicus, $\mathrm{Ka}$ - Karelia australis, $\mathrm{Kl}$ - Karelia ladogensis, Kol - Karelia olonetsensis. All geographical coordinates are given in the spatial reference system WGS 1984. Lichenicolous fungi are marked with \#. The nomenclature of taxa generally follows Nordin et al. (2011), Diederich et al. (2018), and Lawrey \& Diederich (2018). Bacidina indigens is listed following Gerasimova \& Ekman (2017).

\section{THE SPECIES}

BACIDINA Indigens (Vain.) S. Ekman \& J. Gerasimova - SPb, Kronshtadt District, NW part of Kotlin Island, southern shore $\mathrm{W}$ to the fort Shanetz, 6001'33.9”N, 29³9'43.3"E, alt. 1 $\mathrm{m}$, black alder forest with willow and rowan undergrowth on sandy shore, on bark of Salix pentandra L., 20.09.2012, leg. DH \& GT, det. S. Ekman (LECB). - New to European Russia, in Russia known from the Chukotka Autonomous Okrug (Gerasimova \& Ekman, 2017). Distribution in Fennoscandia and Baltic countries: not reported. Distribution in Europe - for example, in Poland (Czarnota \& Coppins, 2007), Germany (Scholz, 2011), and Great Britain (Smith et al., 2009). Our specimen was erroneously reported as $B$. chloroticula (Nyl.) Vězda \& Poelt (Stepanchikova et al., 2015). Similar to $B$. egenula (Nyl.) Vězda, from which it differs by coarsely warted to granular thallus (Fig. 1), and hypothecium which is colourless throughout and $\mathrm{K}$ - (Smith et al., 2009; Gerasimova \& Ekman, 2017).

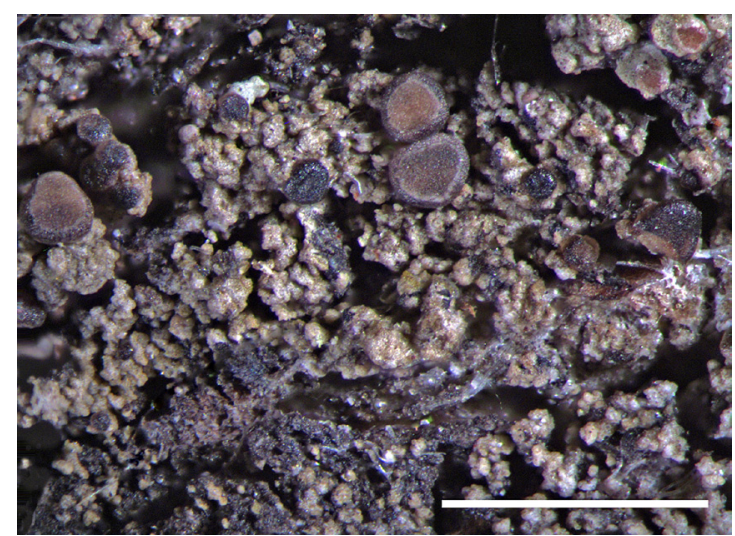

Fig. 1. Thallus and apothecia of Bacidina indigens (LECB). Scale bar $=1 \mathrm{~mm}$.

Bacidina neosquamulosa (Aptroot \& Herk) S. Ekman - WLR, Ka, Kingisepp District, N part of Bolshoy Tuters Island (former Tytärsaari), $59^{\circ} 51^{\prime} 55^{\prime \prime} \mathrm{N}, 27^{\circ} 11^{\prime} 35^{\prime \prime} \mathrm{E}$, black alder stand on the seashore with granite boulders, on bark of Alnus glutinosa (L.) Gaertn., 01.06.2015, leg. IS, det. J. Gerasimova (LECB). - New to WLR, known from $\mathrm{SPb}$ (Himelbrant et al., 2017). Distribution in North-Western European Russia outside of LR: not reported. Distribution in Fennoscandia and Baltic countries: Sweden (Nordin et al., 2011).

Botryolepraria lesdaini (Hue) Canals et al. WLR, Luga District, proposed protected area 'Jaschera-Lemovzha', valley of the Bezhanka River, 58 58'19.4”N, 2942'52.5”E, deep river valley, on red sandstone in dark and humid place, 03.10.2015, leg. DH (H s. n., LECB s. n.). Our three specimens contain lesdainin (6aacetoxyhopan-22-ol) and zeorin. - New to LR. Distribution in North-Western European Russia outside of LR: Republic of Karelia (Fadeeva et al., 2007). Distribution in Fennoscandia and Baltic countries: Norway, Sweden, and Finland (Nordin et al., 2011). Characterized by the pale malachite green diffuse, byssoid, soft and spongy thallus, consisting of a hyphal network with photobiont cell clusters. The photobiont cells are connected to the tips of hyphae but not enclosed by them. The species is restricted to very shadowy sites, such as rocky walls of caves free of dripping water (Canals et al., 1997; Smith et al., 2009).

Bryoria KUEmmerleana (Gyeln.) Brodo \& D. Hawksw. - WLR, Ik, Priozersk District, central part of Konevets Island (in Lake Ladoga), $\mathrm{S}$ of 
Zmeinaya Hill, 6051'52.9'N, 30³6'35.2”E, oldgrowth spruce forest with Sphagnum spp. and Vaccinium myrtillus L., on bark (branches) of Picea abies (L.) H. Karst., 29.07.2017, leg. EK, IS \& DH, conf. L. Myllys (H s. n.). Specimen contains norstictic and connorstictic acids; infected by Lichenostigma maureri Hafellner. - New to NorthWestern European Russia, the nearest locality in Russia is in the Perm Territory (Velmala et al., 2014). Distribution in Fennoscandia and Baltic countries: Norway, Sweden, and Finland (Nordin et al., 2011). Characterized by pruinose brown thallus with elongate fusiform pseudocyphellae, and presence of norstictic acid (Velmala et al., 2014). Although the species is distinct morphologically and chemically, it is treated as synonymous to Bryoria fuscescens (Gyeln.) Brodo \& D. Hawksw. based on molecular data (Boluda et al., 2019).

Caloplaca turkuensis (Vain.) Zahlbr. - WLR, Gatchina District, N of Zapolie village, $59^{\circ} 30^{\prime} 42.2^{\prime \prime}$, 29 $44^{\prime} 02.0$ "E, on bark of old Acer platanoides L. on the edge of field, 14.09.2016, leg. DH \& IS, det. I. Frolov (LECB s. n.). Specimens contain no lichen substances. - New to North-Western European Russia, known from the European part of the Orenburg Region (Šoun et al., 2011) and Southern Siberia (Vondrák et al., 2019). Distribution in Fennoscandia and Baltic countries: Norway, Sweden, and Finland (Nordin et al., 2011, Šoun et al., 2011). Characterized by the apothecia similar to those of Caloplaca cerina (Hedw.) Th. Fr., slightly convex, punctiform to confluent blue-grey soralia, minute or often absent areoles (Fig. 2) (Šoun et al., 2011).

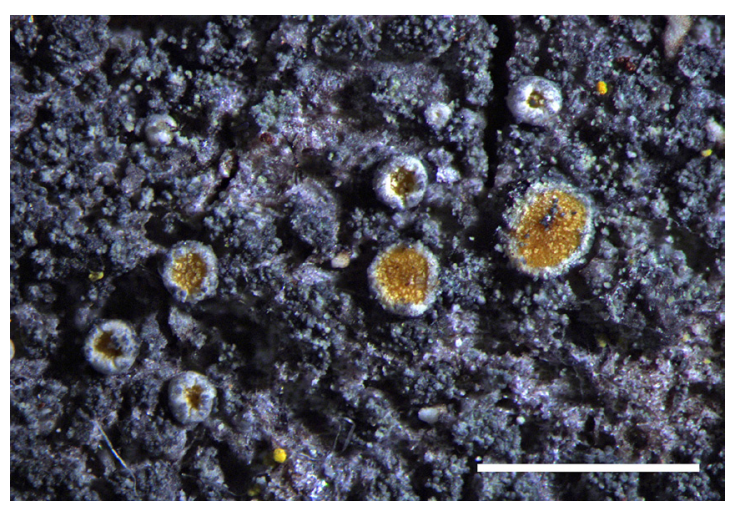

Fig. 2. Thallus, soralia and apothecia of $\mathrm{Ca}$ loplaca turkuensis (LECB). Scale bar $=1 \mathrm{~mm}$.
Lecidella anomaloides (A. Massal.) Hertel \& H. Kilias - WLR, Kl, Priozersk District, ca 5 $\mathrm{km} \mathrm{NW}$ of Sevastyanovo (former Kaukola), the locality formerly named as Laukkaan mäki, $\left[61^{\circ} 05^{\prime} \mathrm{N}, 29^{\circ} 43^{\circ} \mathrm{E}\right]$, on granite boulder in forest, 20.07.1935, leg. M. Laurila (H 8003260); Priozersk District, ca. $5 \mathrm{~km}$ W of Kuznechnoe (former Kaarlahti), vicinity of Bogatyri (former

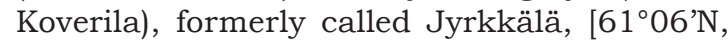
$29^{\circ} 47^{\prime} \mathrm{E}$ ], on wet granite boulder, 28.07.1935, leg. M. Laurila (H s. n.). - New to LR. Distribution in North-Western European Russia outside of LR: Republic of Karelia (Fadeeva et al., 2007), Pskov Region (Istomina \& Likhacheva, 2010). Distribution in Fennoscandia and Baltic countries: Norway, Sweden, and Finland (Nordin et al., 2011). Differs from the other saxicolous Lecidella species by having thin and scattered esorediate gray thallus and entirely dark brown exciple, opaque in section, and preferring siliceous rocks (Smith et al., 2009).

Lecidella Asema (Nyl.) Knoph \& Hertel - WLR, Ka, Vyborg District, Gulf of Vyborg, Berezovye Islands archipelago (former Koivistonsaaret), Berezovye Ostrova Protected Area, W shore of Bol'shoy Solnechny Island (former Suursaari), $60^{\circ} 25^{\prime} 19^{\prime \prime} \mathrm{N}, 28^{\circ} 30^{\prime} 16^{\prime \prime} \mathrm{E}$, on granite seashore boulder, 05.06.2014, leg. IS, DH \& GT (LECB). - New to European Russia. The only record of this species from Russia (Irkutsk Region) by P. L. Nimis \& M. Tretiach is listed in the database of the lichen herbarium of the University of Trieste (TSB 29116) (Nimis \& Martellos, 2017). Distribution in Fennoscandia and Baltic countries: Finland (Nordin et al., 2011). Characterized by granular to verrucose and rimose thick yellow-brown to yellow-green thallus, exciple gray-green to gray-blue at outer edge and pale brown within the section, presence of thiophanic acid in cortex (C+ orange), and coastal habitat (Smith et al., 2009).

Lichenopeltella Peltigericola (D. Hawksw.) R. Sant. - ELR, Boksitogorsk District, ca. $12 \mathrm{~km} \mathrm{E}$ of Svyatozero Lake and ca. $4 \mathrm{~km}$ of Kolp' River, $59^{\circ} 57^{\prime} 35.7^{\prime \prime} \mathrm{N}, 35^{\circ} 24^{\prime} 35.6^{\prime \prime} \mathrm{E}$, mixed forest with birch, aspen, pine and spruce, on upper side of thallus of Peltigera praetextata (Flörke ex Sommerf.) Zopf growing on mosses, 11.05.2018, leg. DH \& IS (BILAS). - New to LR. Distribution in North-Western European Russia outside of LR: Republic of Karelia (Fadeeva et al., 2007). Distribution in Fennoscandia and Baltic coun- 
tries: Norway, Sweden, and Finland (Nordin et al., 2011), Estonia (Randlane et al., 2018). Our specimen was in concurrence with the description in the protologue (Hawksworth, 1982): thyriothecioid acomata 50-60 $\mu \mathrm{m}$ in diam., bearing 3-6 non-septate setae around the ostioles and 1-septate colourless ascospores 15-16 × $4 \mu \mathrm{m}$ (only few mature ascospores were present). The fungus was growing on the upper and lower sides of the host thallus and on rhizines (Fig. 3).

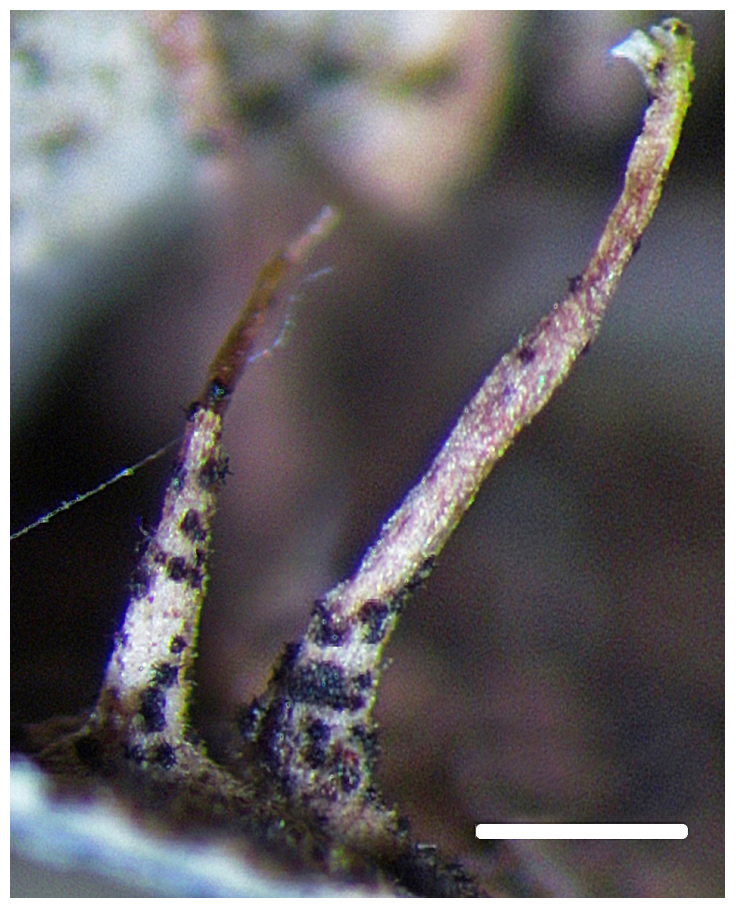

Fig. 3. Ascomata of Lichenopeltella peltigericola on rhizines of Peltigera praetextata (BILAS). Scale bar $=0.5 \mathrm{~mm}$.

\# Muellerella ventosicola (Mudd) D. Hawksw. - WLR, Ik, Priozersk District, W part of Konevets Island (in Lake Ladoga), huge glacial boulder Kon'-Kamen' with chapel of St. Arseniy, $60^{\circ} 51^{\prime} 26.1$ 'N, 30³5'47.1'E, old-growth spruce forest, on thallus of Rhizocarpon sp. growing on granite boulder, 26.07.2017, leg. EK, IS \& DH (BILAS). - New to LR. Distribution in North-Western European Russia outside of LR: Republic of Karelia (Zhurbenko \& Himelbrant, 2002). Distribution in Fennoscandia and Baltic countries: Norway, Sweden (Nordin et al., 2011), and Lithuania (Motiejūnaitè, 2017). Our speci- men was in concurrence with the description provided in Triebel (1989): perithecia 200-350 $\mu \mathrm{m}$ diam., medium- to dark brown, 6.5-7.5 × 4-5 $\mu \mathrm{m}$ ascospores and occurrence on Rhizocarpon.

PROTOBlastenia RUPESTRIS (Scop.) J. Steiner WLR, Ka, Kingisepp District, S shore of Bolshoy Tuters Island, E to Lommosniemi, 59 $50^{\prime} 10^{\prime \prime} \mathrm{N}$, $27^{\circ} 11^{\prime} 56^{\prime \prime} \mathrm{E}$, wasteland on the site of former Finnish village, on concrete of ruins, 29.05.2015, leg. IS, det. U. Schiefelbein (H). - New to WLR, known from ELR (Kuznetsova et al., 2016) and $\mathrm{SPb}$ (Stepanchikova et al., 2017b). Distribution in North-Western European Russia outside of LR: Republic of Karelia (Fadeeva et al., 2007) and Pskov Region (Istomina et al., 2018). Distribution in Fennoscandia and Baltic countries: Norway, Sweden, Finland (Nordin et al., 2011), Estonia (Randlane et al., 2018), Latvia (Āboliña et al., 2015) and Lithuania (Motiejūnaité, 2017).

\# Raesaenenia huUskoneniI (Räsänen) D. Hawksw., C. Boluda \& H. Lindgr. - WLR, Tosno District, vicinity of Trubnikovo railway station, right bank of Tverezna River, [59 $\left.9^{\circ} 7^{\prime} \mathrm{N}, 31^{\circ} 23^{\prime} \mathrm{E}\right]$, pine forest with birch and spruce, on thallus of Bryoria fuscescens on bark (branches) of Pinus sylvestris L., 12.09.1999, leg. O. A. Kataeva (LE, sub B. fuscescens); ELR, Volkhov District, basin of Syas' River, $3.3 \mathrm{~km}$ E of L'zi village, [59 $59^{\circ} \mathrm{N}$, $32^{\circ} 47^{\prime} \mathrm{E}$ ], swampy birch stand with spruce, on thallus of $B$. fuscescens on bark (branches) of Betula sp., 02.2018, leg. B. K. Gannibal (LECB). - New to North-Western European Russia. In European Russia known from Murmansk Region (Urbanavichus et al., 2008). Distribution in Fennoscandia and Baltic countries: Norway, Sweden, and Finland (Nordin et al., 2011). A lichenicolous ascomycete causing extensive black and shiny geniculate deformations on Bryoria spp. (Hawksworth, 1978).

\# Sclerococcum cf. atTendendum (Nyl.) Ertz \& Diederich - ELR, Kol, Podporozhje District, NW to Soginitsy village, right bank of Svyatukha River, 61 ${ }^{\circ} 13^{\prime} 17.4^{\prime \prime} \mathrm{N}, 33^{\circ} 55^{\prime} 30.7^{\prime \prime} \mathrm{E}$, old-growth spruce forest with Sphagnum spp., on thallus of Mycobilimbia sp., growing on spruce log, 21.05.2016, leg. DH \& IS (BILAS). - New to LR. Distribution in North-Western European Russia outside of LR: Republic of Karelia (Fadeeva et al., 2007). Distribution in Fennoscandia and Baltic countries: Norway, Sweden, and Finland (Nordin et al., 2011). According to Lawrey \& 
Diederich (2018) and Triebel (1989), Scleococcum deminutum (Th. Fr.) Ertz \& Diederich inhabits Mycobilimbia spp. and other muscicolous fungi. It is characterized by shiny apothecia and slightly bent, 3-7 septate to submuriform, ascospores. The ascospore size is $13-22 \times$ 5-7.5 $\mu \mathrm{m}$; the spore cells are unequal in size. Hypothecium contains dark violet-blue granules which dissolve in $\mathrm{K}$ and resulting in greenish blue reaction; the same granules are occasionally found also in the excipulum and the lower part of hymenium. However, our specimen (Fig. 4) possesses characteristics largely consistent with $S$. attendendum: dull apothecia, straight ascospores that are (2-)3-septate, 15-17 × 4.5-6 $\mu \mathrm{m}$ [10-17 × 4-6.5 $\mu \mathrm{m}$ in Triebel (1989)] with more or less equal-sized cells and apothecial tissues lacking granules and are $\mathrm{K}-$.
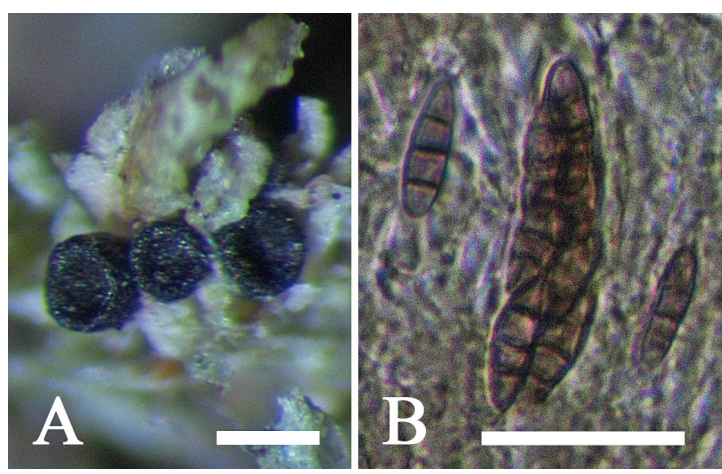

Fig. 4. Sclerococcum cf. attendendum on thallus of Mycobilimbia sp. (BILAS): A - apothecia; $\mathrm{B}-$ ascus and spores. Scale bars: $\mathrm{A}=0.5 \mathrm{~mm}$; $\mathrm{B}=25 \mu \mathrm{m}$.

Scoliciosporum pruinosum (P. James) Vězda - WLR, Ik, Priozersk District, N part of Konevets Island, $60^{\circ} 52 ' 24.8^{\prime \prime} \mathrm{N}, 30^{\circ} 37^{\prime} 11.4 ” \mathrm{E}$, oldgrowth spruce forest with birch, aspen, maple, and black alder, on bark of Alnus glutinosa, 31.07.2017, leg. EK, IS \& DH (H s. n.). - New to North-Western European Russia, the nearest locality in Russia belongs to Kaliningrad Region (Dedkov et al., 2007). Distribution in Fennoscandia and Baltic countries: Sweden, Finland (Nordin et al., 2011) and Estonia (Randlane et al., 2018). Characterized by slightly whitepruinose, white, pale pinkish to yellow- or brown-white apothecia without true exciple, pale epithecium with numerous $\mathrm{K}+$ dissolving crystals, asci Biatora-type, and 3-5 septate sigmoid-curved ascospores, spirally twisted in asci (Smith et al., 2009).

\section{ACKNOWLEDGEMENTS}

Authors thank Stefan Ekman (University of Uppsala, Sweden) for identification of Bacidina indigens and valuable comments, Ulf Schiefelbein (Rostock, Germany) for identification of Protoblastenia rupestris, Julia Gerasimova for identification of Bacidina neosquamulosa, Leena Myllys (University of Helsinki, Finland) who confirmed identification of Bryoria kuemmerleana, and Boris Gannibal (Komarov Botanical Institute, Russia), who collected Raesaenenia huuskonenii. We are also grateful to Mikhail P. Zhurbenko (Komarov Botanical Institute, Russia) and Pier Luigi Nimis (University of Trieste, Italy) for valuable comments on the species distribution. We express our gratitude to an anonymous reviewer and Tiina Randlane (University of Tartu) for valuable corrections. The study was carried out within the framework of the institutional research project "Flora of lichens and bryophytes of Russia and phytogeographically important regions" (no. AAAAA19-119020690077-4) of the Komarov Botanical Institute of the Russian Academy of Sciences.

\section{REFERENCES}

Ābolina, A., Piterāns, A. \& Bambe, B. 2015. Lichens and bryophytes in Latvia. Checklist. Salaspils, Latvijas Valsts mežzinātnes institūts "Silava", DU AA Saule. 213 pp. (In Latvian, English introduction).

Boluda, C. G., Rico, V. J., Divakar, P. K., Nadyeina, O., Myllys, L., McMullin, R. T., Zamora, J. C., Scheidegger, C. \& Hawksworth, D. L. 2019. Evaluating methodologies for species delimitation: the mismatch between phenotypes and genotypes in lichenized fungi (Bryoria sect. Implexae, Parmeliaceae). Persoonia 42: 75-100. https://doi. org/ 10.3767/ persoonia.2019.42.04

Canals, A., Hernandez-Mariné, M., Gómez-Bola, A. \& Llimona, X. 1997. Botryolepraria, a new monotypic genus segregated from Lepraria. Lichenologist 29(4): 339-345. https://doi.org/10.1006/ lich. 1997.0081

Czarnota, P. \& Coppins, B. J. 2007. Contribution to the knowledge of rare Bacidia s. lat. (Lecanorales, lichenized Ascomycetes) from Central Europe including a new, pallid forma of Bacidia hemipolia. Nova Hedwigia 85(3-4): 503-513. https://doi. org/10.1127/0029-5035/2007/0085-0503 
Dedkov, V. P., Andreev, M. P. \& Petrenko, D. E. 2007. Annotated list of lichens of Kaliningrad Region. Biodiversity of Kaliningrad Region. Part 1. Fungi, lichens, club-mosses, horsetails and ferns of Kaliningrad Region. Kaliningrad. Pp. 79-178. (In Russian).

Diederich, P., Lawrey, J. D. \& Ertz, D. 2018. The 2018 classification and checklist of lichenicolous fungi, with 2000 nonlichenized, obligately lichenicolous taxa. Bryologist 121(3): 340-425. https://doi. org/10.1639/0007-2745-121.3.340

Fadeeva, M. A., Golubkova, N. S., Vitikainen, O. \& Ahti, T. 2007. Conspectus of lichens and lichenicolous fungi of the Republic of Karelia. Petrozavodsk. 194 pp. (In Russian, English summary).

Gerasimova, J. V. \& Ekman, S. 2017. Taxonomy and nomenclature of seven names in Bacidia (Ramalinaceae, Lecanorales) described from Russia. Phytotaxa 316(3): 292-296. https:/ / doi. org/10.11646/phytotaxa.316.3.9

Hawksworth, D. L. 1978. Notes on British lichenicolous fungi: II. Notes from the Royal Botanical Garden Edinburgh 36: 181-198.

Hawksworth, D. L. 1982. Notes on British lichenicolous fungi: IV. Notes from the Royal Botanical Garden Edinburgh 40: 375-397.

Himelbrant, D. E., Stepanchikova, I. S., Kuznetsova, E. S., Motiejūnaitè, J. \& Konoreva, L. A. 2018. Konevets Island (Leningrad Region, Russia) - a historical refuge of lichen diversity in Lake Ladoga. Folia Cryptogamica Estonica 55: 51-78. https:/ / doi.org/10.12697/fce.2018.55.07

Himelbrant, D. E., Stepanchikova, I. S., Motiejūnaitè, J., Gagarina, L. V. \& Dyomina, A. V. 2016. New records of lichens and allied fungi from the Leningrad Region, Russia. VII. Folia Cryptogamica Estonica 53: 25-34. https://doi.org/10.12697/ fce.2016.53.04

Himelbrant, D. E., Stepanchikova, I. S., Motiejūnaitė, J., Gerasimova, J. V., Kuznetsova, E. S., Dyomina, A. V. \& Tsurykau, A. G. 2017. New records of lichens and allied fungi from the Leningrad Region, Russia. VIII. Folia Cryptogamica Estonica 54: 6370. http://dx.doi.org/10.12697/fce.2017.54.11

Istomina, N. B. \& Likhacheva, O. V. 2010. The preliminary list of lichens of the Pskov Region (Russia). Novitates Systematicae Plantarum Non Vascularium 44: 171-199. (In Russian, English summary).

Istomina, N. B., Likhacheva, O. V., Stepanchikova, I. S., Kuznetsova, E. S., \& Himelbrant, D. E. 2018. New and rare lichens and allied fungi from the Pskov Region, Russia. Folia Cryptogamica Estonica 55: 21-31. https://doi.org/10.12697/ fce.2018.55.04

Kotiranta, H., Uotila, P., Sulkava, S. \& Peltonen, S.-L. (eds). 1998. Red Data Book of East Fennoscandia. Helsinki. 351 pp.

Kuznetsova, E. S., Kataeva, O. A., Himelbrant, D. E. \& Motiejūnaitè, J. 2016. Lichens and allied fungi of the Ragusha River Protected Area (Leningrad Region, Russia). Folia Cryptogamica Estonica 53: 71-80. https://doi.org/10.12697/fce.2016.53.09 Kuznetsova, E. S., Motiejūnaitè, J., Stepanchikova, I. S., Himelbrant, D. E. \& Czarnota, P. 2012. New records of lichens and allied fungi from the Leningrad Region, Russia. III. Folia Cryptogamica Estonica 49: 31-37.

Lawrey, J. D. \& Diederich, P. 2018. Lichenicolous fungi - worldwide checklist, including isolated cultures and sequences available. URL: http:/ / www.lichenicolous.net [1/3/2018].

Motiejūnaitè, J., 2017. Supplemented checklist of lichens and allied fungi of Lithuania. Botanica Lithuanica 23(2): 89-106. https://doi.org/10.1515/ botlit-2017-0011

Nimis, P. L. \& Martellos, S. 2017. ITALIC - The Information System on Italian Lichens. Ver. 5.0. University of Trieste, Department of Biology. - http: / / dryades.units.it/italic (23 March 2019).

Nordin, A., Moberg, R., Tonsberg, T., Vitikainen, O., Dalsatt, A., Myrdal, M., Snitting, D. \& Ekman, S. 2011. Santesson's Checklist of Fennoscandian Lichen-forming and Lichenicolous Fungi. Ver. April 29, 2011 - http://130.238.83.220/santesson/ home.php (23 March 2019).

Orange, A., James, P. W. \& White, F. J. 2001. Microchemical methods for the identification of lichens. London. $101 \mathrm{pp}$.

Randlane, T., Saag, A. \& Suija, A. 2018. Lichenized, lichenicolous and allied fungi of Estonia. Ver. December 31, 2018 - http://esamba.bo.bg.ut.ee/ checklist/est/home.php (23 March 2019).

Scholz, P. 2011. Bacidia viridescens - Erstmals in Deutschland Nachgewiesen. Herzogia 24(2): 371-373. https://doi.org/10.13158/ heia.24.2.2011.371

Smith, C. W., Aptroot, A., Coppins, B. J., Fletcher, A., Gilbert, O. L., James, P. W. \& Wolseley, P. A. (eds). 2009. The lichens of Great Britain and Ireland. The British Lichen Society, London. 1046 pp.

Šoun, J., Vondrák, J., Søchting, U., Hrouzek, P., Khodosovtsev, A. \& Arup, U. 2011. Taxonomy and phylogeny of the Caloplaca cerina group in Europe. Lichenologist 43(2): 113-135. https:/ / doi. org/10.1017/S0024282910000721

Stepanchikova, I. S., Andreev, M. P., Himelbrant, D. E., Motiejūnaite, J., Schiefelbein, U., Konoreva, L. A. \& Ahti, T. 2017a. The lichens of Bolshoy Tuters Island (Tytärsaari), Leningrad Region, Russia. Folia Cryptogamica Estonica 54: 95-116. https:/ / doi.org/10.12697/fce.2017.54.14

Stepanchikova, I. S., Himelbrant, D. E., Dyomina, A. V. \& Tagirdzhanova, G. M. 2015. The lichens and allied fungi of the Zapadny Kotlin protected area and its vicinities (Saint Petersburg). Novitates Systematicae Plantarum Non Vascularium 49: 265-281. 
Stepanchikova, I. S., Himelbrant, D. E. \& Kuznetsova, E. S. 2017b. Lichens. - In: The nature of Ozero Schuchie Protected Area. Saint-Petersburg: 97-113. (In Russian, English summary).

Stepanchikova, I. S., Himelbrant, D. E., Motiejūnaite, J., Ahti, T., Suja, A., Kuznetsova, E. S. \& Dyomina, A. V. 2018. New records of lichens and allied fungi from the Leningrad Region, Russia. IX. Folia Cryptogamica Estonica 55: 117-124. https://doi. org/10.12697/fce.2018.55.12

Stepanchikova, I. S., Kukwa, M., Kuznetsova, E. S., Motiejūnaite, J. \& Himelbrant, D. E. 2010. New records of lichens and allied fungi from the Leningrad Region. Folia Cryptogamica Estonica 47: 77-84.

Triebel, D. 1989. Lecideicole Ascomyceten. Eine Revision der obligat lichenicolen Ascomyceten auf lecideoiden Flechten. Bibliotheca Lichenologica 35: $1-278$.
Urbanavichus, G. P., Ahti, T. \& Urbanavichene, I. N. 2008. Catalogue of lichens and allied fungi of Murmansk Region, Russia. Norrlinia 17: 1-80.

Velmala, S., Myllys, L., Goward, T., Holien, H. \& Halonen, P. 2014. Taxonomy of Bryoria section Implexae (Parmeliaceae, Lecanoromycetes) in North America and Europe, based on chemical, morphological and molecular data. Annales Botanici Fennici 51: 345-371. https://doi. org/10.5735/085.051.0601

Vondrák, J., Frolov, I., Davydov, E. A., Yakovchenko, L., Malíček, J., Svoboda, S. \& Kubásek, J. 2019. The lichen family Teloschistaceae in the Altai-Sayan region (Central Asia). Phytotaxa 396(1): 1-66. https://doi.org/10.11646/phytotaxa.396.1.1

Zhurbenko, M. P. \& Himelbrant, D. E. 2002. Lichenicolous fungi from the Kandalaksha Gulf, Karelia Keretina, Russia. Folia Cryptogamica Estonica 39: 51-59. 
30 Folia Cryptog. Estonica 